\title{
Labour Market Segmentation Revisited: A Study of the Dutch Call Centre Sector
}

Citation for published version (APA):

de Grip, A., Sieben, I. J. P.., \& van Jaarsveld, D. (2006). Labour Market Segmentation Revisited: A Study of the Dutch Call Centre Sector. Researchcentrum voor Onderwijs en Arbeidsmarkt, Faculteit der Economische Wetenschappen. ROA Working Papers No. 008E https://doi.org/10.26481/umarow.2006008E

Document status and date:

Published: 01/01/2006

DOI:

10.26481/umarow.2006008E

Document Version:

Publisher's PDF, also known as Version of record

\section{Please check the document version of this publication:}

- A submitted manuscript is the version of the article upon submission and before peer-review. There can be important differences between the submitted version and the official published version of record.

People interested in the research are advised to contact the author for the final version of the publication, or visit the DOI to the publisher's website.

- The final author version and the galley proof are versions of the publication after peer review.

- The final published version features the final layout of the paper including the volume, issue and page numbers.

Link to publication

\footnotetext{
General rights rights.

- You may freely distribute the URL identifying the publication in the public portal. please follow below link for the End User Agreement:

www.umlib.nl/taverne-license

Take down policy

If you believe that this document breaches copyright please contact us at:

repository@maastrichtuniversity.nl

providing details and we will investigate your claim.
}

Copyright and moral rights for the publications made accessible in the public portal are retained by the authors and/or other copyright owners and it is a condition of accessing publications that users recognise and abide by the legal requirements associated with these

- Users may download and print one copy of any publication from the public portal for the purpose of private study or research.

- You may not further distribute the material or use it for any profit-making activity or commercial gain

If the publication is distributed under the terms of Article $25 \mathrm{fa}$ of the Dutch Copyright Act, indicated by the "Taverne" license above, 


\title{
Labour Market Segmentation Revisited:
} A Study of the Dutch Call Centre Sector

\author{
ROA-W-2006/8E
}

Andries de Grip, Inge Sieben, Danielle van Jaarsveld*

* Sauder School of Business, University of British Columbia, Vancouver, Canada

Research Centre for Education and the Labour Market

Faculty of Economics and Business Administration

Maastricht University

Maastricht, October 2006 
ISBN 10: 90-5321-446-1

ISBN-13: 978-90-5321-446-6

Sec06.112.doc 


\section{Contents}

Page

1 Introduction 1

2 Labour market segmentation theory 2

3 Methodology 2

$4 \quad$ Background: Dutch call centre sector 3

$5 \quad$ A segmented labour market? $\quad 4$

6 Workforce Flexibility $\quad 7$

$7 \quad$ Developments and industrial relations 10

$\begin{array}{ll}\text { Conclusions } & 12\end{array}$

$\begin{array}{ll}\text { References } & 13\end{array}$ 



\section{Introduction}

Employment in the call centre sector in the Netherlands, similar to the trend in other European countries, is expanding greatly. In 2001, Datamonitor (2002) estimated that 1,266 call centres were operating in the Netherlands. This number is expected to have risen to roughly 2,000 in 2006 . An estimated 188,000 people work in this sector at the moment, representing $2.5 \%$ of the entire working population in the Netherlands. This represents the highest percentage in Europe with the exception of Ireland. The call centre workforce is employed by in-house and subcontractor call centres. In-house call centres are part of the firm for which they handle customer contacts, whereas subcontractor call centres, which provide customer contact services for other firms or institutions.

The call centre sector features a large number of employees working in so-called atypical employment contracts, in particular 'agents' who handle the actual customer contacts (De Grip, Hoevenberg \& Willems, 1997). Agents are often hired into temporary appointments, part-time contracts, irregular shifts, stand-by contracts, et cetera. The use of such atypical contracts is closely related to the great need for flexibility in the deployment of staff (Kalleberg, 2000). Such workforce flexibility is necessary in order to negotiate peaks and valleys in call volumes. In addition, many call centres prioritize on cost reduction, and this approach constrains investment in personnel. Call centres are therefore often classified as 'electronic sweatshops' offering only 'dead-end jobs' (Taylor, et al., 2002; Deery \& Kinnie, 2004).

The labour market for call centre agents could thus be characterised as a 'secondary labour market' of insecure, poorly paid jobs without any career opportunities (see e.g. Dekker, De Grip \& Heijke, 2002). However, the call centre sector is heterogeneous with respect to employment conditions. For example, agents who work in in-house call centres have better employment conditions than their counterparts in subcontractor call centres. The Dutch industrial relations system offers one explanation for this difference. Agents working in in-house call centres have protections defined by the collective labour agreement (CLA) of the firm the call centre agents work in. In contrast, the subcontractor call centres did not have any comparable protections or their own CLA until 2003. The establishment of a CLA that covers agents employed in Dutch subcontractor call centres in 2003 is a unique phenomenon in the European call centre market (Roland, 2000b).

The difference in working conditions between in-house and subcontractor call centres raises the following research question addressed in this paper: To what extent is the labour market for call centre agents a dual labour market, with a secondary segment in the subcontractor call centres, and a primary segment in the form of a 'professional labour market' in the in-house call centres?

To answer this question, we analyze survey data collected from a national survey of call centre managers in the Netherlands. Moreover, we investigate whether the aforementioned need for workforce flexibility may provide an explanation for the labour market segmentation in the call centre sector and if this segmentation is embedded in Dutch industrial relations.

We begin with a brief overview of labour market segmentation theory. Next, we describe the dataset, and provide some brief background about the Dutch call centre sector and its workforce. Then, we investigate the differences between employment conditions in in-house and subcontractor call centres, to determine whether there is a segmented labour markets. 
Finally, we assess the influence of industrial relations in the call centre sector, and determine whether these reflect the labour market segmentation.

\section{Labour market segmentation theory}

Labour market segmentation theory (see e.g., Doeringer \& Piore, 1971) initially distinguishes two labour market segments, the one characterised by better, permanent, well-paid jobs with career prospects (the 'primary segment'), and the other having temporary, badly paid jobs without any career prospects (the 'secondary segment'). This type of labour market is referred to as a 'double' or 'dual' labour market. Within the primary segment of the labour market, a distinction is often made between internal labour markets that operate within firms, and profession-specific submarkets (Osterman, 1982). Internal labour markets exist in large firms that want to create a well-trained labour force, and protect their internal labour market against the external labour market. Profession-specific submarkets, on the other hand, are external labour market segments for groups of workers trained for a specific profession who can be deployed productively in a number of firms. The division of the primary segment of the labour market into internal labour markets and profession-specific submarkets helps to define the secondary segment of the labour market more accurately. Those who work in the latter segment of the labour market have a weak link with the labour market. They lack a steady connection with a particular firm, but they also lack a permanent link with a particular occupation or profession. One of the defining characteristics of a secondary labour market therefore is a high level of labour turnover (Alexander, 1974). One of the consequences of the absence of a steady connection with a particular firm or profession is that both employers and employees invest as little as possible in additional training, although added the note that the secondary segment of the labour market sometimes acts as the filtering stage for an internal labour market. In summary, the segmentation literature yields the following characteristics for a secondary labour market relative to the primary market (Doeringer \& Piore, 1971): low wages, poor additional benefits, poor working conditions, little additional training, a large number of temporary contracts, a high level of part-time work, few career opportunities ${ }^{1}$, and a high turnover rate. In addition to the aforementioned characteristics, the relatively low education level of workers is also regarded as a characteristic of a secondary labour market. Dekker, De Grip \& Heijke (2002), however, have shown that the character of the secondary labour market has changed as far as this is concerned. It also provides (temporary or other) work for those with a secondary or higher education.

\section{Methodology}

One difficulty in studying the call centre sector is that it is a relatively new sector, and is completely absent from all relevant official statistics. Moreover, it is also difficult to isolate the call centre sector from other industries as many in-house call centres are located across

1. Particularly compared to the firm's internal labour market. 
industry lines. Hence, sparse up-to-date information is available on personnel and labour market developments in this sector, which also complicates the development of industrial relations at a central level. The lack of objective data may easily feed differences in interpretations between government, employers, and trade unions on the importance of certain developments or problems that manifest themselves in the sector.

We have started to address this deficiency by collecting information on several aspects relating to employment conditions in the call centre sector. Our study is part of the Global Call Centre Industry Project. ${ }^{2}$ A total of 21 countries took part in this study: Australia, Austria, Brazil, Canada, Denmark, France, Germany, Great Britain, Ireland, India, Israel, Japan, Netherlands, Norway, Philippines, Poland, South Africa, South Korea, Spain, Sweden and the United States. Similar to the research approach implemented in the participating countries, the Dutch study consisted of two parts:

- A survey administered to managers of in-house and subcontractor call centres, to collect quantitative data on a variety of aspects of personnel issues, personnel policies, and industrial relations within the firm.

- Qualitative case studies based on structured interviews with the general manager, an HRM manager, an IT manager, and a team leader or supervisor of six in-house and three subcontractor call centres.

Moreover, structured interviews were conducted with representatives from the largest Dutch trade union FNV, the employers' association for in-house call centres VCN, and the employers' association for subcontractor call centres WGCC. In addition, we interviewed managers from a number of temporary job agencies specialising in call centre employment.

For the survey of call centre managers, we established a connection to the National Contact Centre Benchmark Platform study. This survey is held every year - for the seventh time in 2004 - and is sent to around 800 call centre managers in the Netherlands. Written responses were returned during the period between April and July 2004. In total, we received responses from 116 managers (response rate of 14.5\%).

\section{Background: Dutch call centre sector}

Call centres are organisations or parts of organisations whose task it is to handle nonphysical customer contact, for example by phone, Internet, fax or post. Our survey shows that the Dutch call centre market is dominated by in-house call centres (72\%). The other call centres are "subcontractor" call centres, providing customer contact services for other firms. In-house call centres are distributed across several sectors, including retail trade, media and tourism (25\%), and financial services (19\%). Other sectors where we found concentrations of in-house call centres include telecommunications, commercial services and IT (15\%), the public sector (government, police, etc.), and utility companies (13\%).

The type of work handled by in-house and subcontractor call centres is an important source of difference that may influence the divergent working conditions for agents. For

2. The Global Call Centre Industry Project was initiated by Rose Batt from Cornell University, USA and Stephen Wood and David Holman of Sheffield University, UK. (Authors C) have provided an extensive report on the Dutch survey. 
example, a large difference in the type of calls handled in in-house and subcontractor call centres exists. The majority of in-house call centres (94\%), handle so-called inbound calls, i.e. calls made at the initiative of the customer (for example to ask for information, to make purchases, submit complaints, etc.). In comparison, only $34 \%$ of the subcontractor call centres handle inbound calls. On the other hand, $38 \%$ of subcontractor call centres handle primarily outbound calls. $59 \%$ of the subcontractor call centres handle sales calls; for the inhouse call centres this percentage is only $13 \%$. For $86 \%$ of the in-house call centres, most calls are customer service calls.

The largest group of call centre workers consists of the agents, who handle the frontline of contact with customers. Compared to those in neighbouring countries, Dutch call centres are fairly large (cf. Holtgrewe, 2005; Lanciano-Morandat, et al., 2005). On average, subcontractor call centres are larger than in-house call centres with 290 agents, whereas inhouse call centres have on average 127 agents. We also find that subcontractor call centres supervise their agents to a greater extent: on average, there is one team leader for every eleven agents. In in-house call centres, one team leader is responsible for - on average fifteen agents. Examining call centre work, we find that subcontractor call centres employ a considerably higher number of young people than in-house call centres. For example, 39\% of all agents employed in subcontractor call centres is under 25 years old; in in-house call centres, this applies to only $24 \%$. Subcontractor call centres also employ a greater number of agents with higher education levels: $24 \%$ has studied at college or university level, compared with $15 \%$ in in-house call centres. The latter may be related to the specific nature of the services usually rendered by subcontractor call centres, such as providing IT helpdesk services. Another explanation for this difference may be that the agents are students who are in the process of completing their studies, or people who have completed their studies, but temporarily accept a job in a call centre to bridge the time between graduation and finding a job that matches their education.

\section{A segmented labour market?}

In this section, we will discuss to what extent the call centre sector has a dual labour market, with better jobs in the in-house call centres and lesser jobs in subcontractor call centres. However, if there is a clear dichotomy in the labour market for call centre agents when it comes to the available jobs, then this need not mean that the better jobs in the inhouse call centres should automatically be classified as a primary labour market. The agents in these call centres often have only a loose link with the labour market: annually, $11 \%$ of them leave the call centre, $59 \%$ has a part-time contract, and the case studies show that these agents often have limited career prospects. As described above, these are the typical characteristics of jobs offered in a secondary labour market. A possible dichotomy between the labour market position of agents working in subcontractor call centres and agents in inhouse call centres, may therefore indicate a further division of the secondary segment of the labour market. To obtain more insight, we will outline and compare several aspects of the labour market position of agents working in in-house call centres and agents working in subcontractor call centres. In doing so, we will look at the factors that the labour market segmentation theory regards as indicators for the existence of a secondary labour market. 
We will first evaluate the average hourly wages, additional benefits, labour conditions, training participation, and career prospects. Then we will discuss the indicators relating to the call centres' need for workforce flexibility: part-time jobs, temporary jobs and employee turnover.

Table 1 shows that the average hourly wages of agents in subcontractor call centres is more than $17 \%$ below that of their in-house counterparts. Large differences also exist when considering access to additional benefits such as pensions, save-as-you-earn initiatives ${ }^{3}$, and disablement insurance. The majority of in-house call centres offer these benefits to their customer service representative workforce. In contrast, these benefits are much less likely to be available in the subcontractor call centre setting. For example, only $39 \%$ of subcontractor call centres offer pensions to their workforce, and only $54 \%$ of subcontractor call centres offer their agents access to a save-as-you-earn program.

Table 1

Terms of employment, working conditions and training participation of agents working in inhouse call centres and agents in subcontractor call centres

$\begin{array}{ll}\text { In-house } & \text { Subcontractor } \\ \text { call centre } & \text { call centre }\end{array}$

Primary terms of employment

Average gross hourly wages

$€ 13.80$

$€ 11.40$

Additional terms of employment

Pension scheme

Reimbursement of travelling expenses

$100 \% \quad 39 \%$

$97 \% \quad 96 \%$

Save-as-you-earn program

$97 \% \quad 54 \%$

Coverage of disablement risk

$83 \% \quad 35 \%$

Working conditions

Formal occupational health and safety policy

$94 \%$

$78 \%$

Average size of workplaces

Partition walls

Adjustable desk height

Air conditioning

Flat screens for all agents

Entry training

Average investment in entry training

Average number of training hours in 2003:

- outbound agents

$7.5 \mathrm{~m}^{2}$

$6.5 \mathrm{~m}^{2}$

$66 \%$

$69 \%$

$84 \%$

$69 \%$

$84 \%$

$69 \%$

$48 \%$

$29 \%$

- inbound agents

$€ 5,783$

Additional training

Average number of training hours in 2003:

- outbound agents

85 hours

18 hours

83 hours

33 hours

- inbound agents

20 hours

21 hours

43 hours

25 hours

Source: NCCPB 2004

3. Save-as-you-earn programs allow employees to save money with a tax deduction. 
Beyond the terms of employment, working conditions are also less favourable in subcontractor call centres compared with in-house call centres. For example, subcontractor call centres are far less likely compared to in-house call centres to have formal Occupational Health and Safety policies (cf. Taylor, et al., 2003). Distinct differences also extend to workplace facilities. Agents in subcontractor call centres, on average, have smaller workplaces, less comfortable desks, and less often air conditioning at their places of work. Subcontractor call centres also less often use flat-screen monitors for all of their agents. On the other hand, subcontractor call centres slightly more often have partitions between the workplaces.

Table 1 also shows that subcontractor call centres invest far less in entry level training for their agents. The subcontractor call centres, on average, spend only $€ 1,877$ on this, compared with $€ 5,783$ in the in-house call centres. This difference can also be found in the number of hours spent on entry training. In subcontractor call centres, agents who handle outbound calls receive - on average - only 18 hours of training before they are deployed in production. In in-house call centres, the number of training hours of agents handling outbound calls is much higher: on average 85 hours. In contrast, the much smaller group of agents who handle inbound calls in subcontractor call centres (including the IT help desks), receives slightly more entry training (33 hours), but this still is less training than inbound agents working in in-house call centres receive.

There are also large differences in the degree to which agents receive additional courses and training after their initial training. Inbound agents with more experience, in subcontractor call centres, for example, received - on average - only 25 hours of additional training in 2003, while inbound agents working in in-house call centres received 43 hours of training. On the other hand, there is a negligible difference in the number of hours spent on training for outbound agents: 21 hours in subcontractor call centres against 20 hours in in-house call centres. The relatively higher amount of training hours for outbound agents in subcontractor call centres is probably due to the different client firms for which the call centre works, as a result of which agents constantly need to acquire new information on the firm, the product, and the specific sales campaign for which they are employed.

The interviews with call centre managers revealed that the career prospects for agents in both in-house and subcontractor call centres with a few exceptions are still limited. The career opportunities available within a call centre include the level of team leader or supervisor. In theory, careers to higher management positions are possible, but in practice this is rarely achieved by agents. Some organizations in the in-house context use the call centre as an entry point into the organization. Therefore, agents working in in-house call centres have the possibility to transfer outside of the call centre to a different part of the organisation. For example, agents who work in a banking call centre, may accept a job in a local bank office. For young people without any experience in banking, an opportunity to work in a call centre may be the first step in their careers, because they are able to acquire a great deal of sector- and firm-specific knowledge in the call centre. 


\section{Workforce Flexibility}

Three key indicators of a secondary labour market are closely related to the great need for workforce flexibility in call centres: the high incidence of part-time workers and temporary staff, and a high turnover rate. First, the use of part-time staff is an important tool for many call centres to avail themselves of a flexible workforce, which they may use to cope with peaks in call volumes during the week or during the workday (cf. Taylor \& Bain, 1999). Table 2 illustrates that in in-house call centres no less than 59\% of all agents have part-time contracts. The use of part-time workers is even more widespread in subcontractor call centres: $77 \%$ of all agents in these call centres works on a part-time basis. The large number of agents with part-time contracts also offers Dutch call centres a major competitive advantage compared to call centres in other countries, where in particular women with a working partner are much less inclined to look for part-time work. In Germany, for example, only $43 \%$ of all agents have part-time contracts (Holtgrewe, 2005), while the percentage in France is a mere 14\% (Lanciano-Morandat, et al., 2005). The Netherlands' reputation as the "only part-time economy in the world" (Freeman, 1998) in part accounts for the decision by several call centres serving the European market to locate in the Netherlands.

Table 2

Flexibility of agents working in in-house call centres and agents in subcontractor call centres

$\begin{array}{ll}\text { In-house } & \begin{array}{l}\text { Subcontractor } \\ \text { call centre }\end{array} \\ \text { call centre }\end{array}$

Part-time work

Percentage of part-time workers $\quad 59 \% \quad 77 \%$

Job agencies

Percentage of call centres using temporary workers $\quad 61 \% \quad 74 \%$

Percentage of call centres recruiting through job

agencies

Average percentage of temporary workers

Average duration of temporary work

Recruitment problems

Percentage of call centres with recruitment problems

Worker turnover (annually)

Voluntary

Termination of contract or redundancy

Total turnover

$66 \% \quad 79 \%$

$16 \% \quad 25 \%$

9.4 months $\quad 6.6$ months

$36 \% \quad 53 \%$

$4 \% \quad 8 \%$

$7 \% \quad 11 \%$

$11 \%$

Source: NCCBP 2004

In addition to part-time staff, Dutch call centre managers often rely on temporary personnel to cope with business fluctuations during the course of a year. $61 \%$ of in-house call centres and $74 \%$ of subcontractor call centres employ temporary staff that works for a job agency. The reliance of Dutch call centres on temporary staff, and their close relationship with temporary agencies is another distinguishing characteristic of the call centre sector in the Netherlands compared with other European countries. In Germany, by comparison, only $15 \%$ of the call centres use temporary staff (Holtgrewe, 2005). The extensive use of temporary staff in the Netherlands is in part accounted for by the relatively strong labour 
market position and legislative protections of temporary staff in the Netherlands, and the acceptance by unions of the employers' use of temporary workers (Koene, et al., 2004). For example, the Collective Labour Agreement for Temporary Workers allows for temporary staff to be attached to a temporary job agency for prolonged periods of time. Temporary staff may even have a permanent contract with a temporary agency. As a result of these relatively favourable terms of employment, temporary agencies are able to mediate on behalf of much greater numbers of temporary staff, who can be easily deployed as call centre agents, than is the case in other countries. Although the costs of temporary staff - because of their strong labour market position - are higher than if the call centre were to recruit temporary staff itself, appointing temporary staff is very attractive for call centres. It enables them to respond immediately and efficiently to fluctuations in turnover, without a decrease in workload - and hence, the productivity - of individual workers. In addition, it prevents any redundancy costs.

Most Dutch call centres therefore employ temporary workers. A total of $66 \%$ of the inhouse call centres use a temporary agency when recruiting staff. In the subcontractor call centres, this even applies to $79 \%$ of the call centres. Of all agents working in in-house call centres, $16 \%$ have a contract with a temporary agency. In the subcontractor call centres, this percentage is even higher: no less than $25 \%$ of all agents working in these call centres, have a contract with a temporary agency. On average, temporary staff in in-house call centres are posted for 9.4 months. With subcontractor call centres, the average term of employment is much shorter: 6.6 months.

Another characteristic of the position of temporary workers in the Netherlands is that a number of these workers eventually obtain a permanent contract with the call centre for which they work. Therefore, the purpose in hiring temporary staff on the one hand is to deal with unexpected fluctuations in demand, while on the other it offers call centres an opportunity to test an agent with minimal risk. This applies to about one third of the temporary workers. The relationship between call centres and temporary agencies is therefore quite close in many cases. Many Dutch call centres work closely together with one or two dedicated temporary agencies, which not only supply the call centres with temporary staff, but also offer an extensive set of services relating to the recruitment and selection of staff, and agent training. Call centres often sign contracts with the temporary agencies in which they agree on the total number of temporary workers to be supplied within a particular period of time, and the call centre may stipulate several conditions the temporary workers selected by the job agency must comply. The job agency, therefore often, tests the applicants first for their typing skills and communication competencies. Job agencies that specialise in call centre work often also provide the required additional coaching. This usually consists of basic training in conversation techniques, and customer service.

The important role that job agencies play in the Dutch call centre sector is related to the nature of the labour market segment in which call centres recruit most of their personnel. They are often searching for people who want to work part-time, and who are willing to accept temporary jobs. As these jobs are not very attractive to the majority of the work force, many call centres find it difficult to recruit new personnel, despite the current surplus on the labour market. No less than $30 \%$ of the in-house call centres and $53 \%$ of subcontractor call centres encounter these difficulties. The large number of temporary workers in the Dutch call centre sector is possibly also related to the high rate of absenteeism amongst longer tenure agents. This high rate of absenteeism is related to the stressful nature of call centre work 
and the often physically straining working conditions - that increase in intensity over the longer term (Holman, 2002). Absenteeism is highest amongst agents in in-house call centres. In these call centres, no less than $10.2 \%$ of all working hours are lost through the absenteeism of agents. In the subcontractor call centres, absenteeism averages around 9.1\%. Among temporary agents, absenteeism is considerably lower. In particular in in-house call centres, the difference with agents working on the basis of a permanent contract is great: $6.5 \%$ against $10.2 \%$. In subcontractor call centres, the difference is smaller: $7.5 \%$ against $9.1 \%$.

Finally, the dichotomy in the labour market positions of agents is also clearly reflected in turnover rates. Although worker turnover in Dutch call centres is fairly low, compared to other European countries, ${ }^{4}$ (cf. Holman, et al., 2005; Holtgrewe, 2005), it is considerably higher than in other industrial sectors in the Netherlands. For example, total turnover rates among agents employed in in-house call centres are already at a high level (11\% on average in 2003) - which indicates that this is indeed a secondary labour market (see Alexander, 1974) - but in subcontractor call centres turnover rates are no less than $19 \%$. The difference in worker turnover rates between the subcontractor and in-house call centres relates both to the so-called 'voluntary turnover', and to involuntary turnover (termination of employment contracts or redundancy). In subcontractor call centres, the average voluntary turnover rate is $8 \%$, compared with $4 \%$ in in-house call centres; involuntary turnover averages around $11 \%$ and $7 \%$, respectively. Both the high levels of voluntary and involuntary turnover amongst agents in subcontractor call centres, suggest a weak bond between agents and the firm for which they work.

The differences between agents working in subcontractor call centres and agents working in in-house call centres described above, clearly indicate a further segmentation of the secondary labour market within the call centre sector. Still, a limited number of agents working in in-house call centres do have jobs in the primary segment of the labour market. The case studies revealed this particularly holds for in-house call centres of multinational companies in banking and the automotive sector.

Labour market segmentation within in-house call centres is closely related to the customer segmentation in call centres, when key customers are handled by higher qualified agents (Batt, 2001). We found some evidence of segmentation in our interviews with a major Dutch bank. This bank had two separate call centres: one for business customers, and another for private customers. The majority of agents serving business customers worked full-time during regular office hours. They were well-trained and had long tenure with the bank. The call centre for private customers had a separate 'top desk' for key customers, who were connected to this desk automatically on the basis of their bank account number. The agents working for this top desk were also well-trained and were able to handle any kind of banking services. The agents who handled the contacts with other customers were able to provide only a limited number of services (e.g. payments and savings) and transferred customers to a different department in the call centre for other services.

4. Worker turnover in American call centres is much higher even, and is estimated to be 30 to $50 \%$ (Batt, Doellgast \& Kwon, 2005). 


\section{Developments and industrial relations}

Finally, we will outline how the segmentation of the labour market for call centre agents is embedded in Dutch industrial relations, and which developments have occurred there in the last few years. The latter is interesting in particular because industrial relations in this relatively young sector may appear to have some distinguishing features absent from those sectors that have a long tradition in this field (Roland, 2000a). In addition, call centres often have the possibility of settling at locations where there are few constraints on their operations. While significant media attention has focused on the movement of call centre work from the US to India, call centres in the Dutch market are much less transient, although a few companies have moved their call centres to South Africa or Surinam. Several multilingual call centres servicing European countries from a single location are also located in the Netherlands. These call centres settle preferably in countries in which labour costs are relatively low and the need for flexibility can be met best, although it must be added that for these call centres it is at least equally important that there are enough native speakers of the various European languages available at such a location.

At the beginning of this paper, we mentioned that the dual nature of the labour market for call centre agents is an outcome of the different CLAs applying to the agents. Those who work in Dutch in-house call centres are usually covered by the CLA for the firm or sector in which the call centre operates (Roland, 2000b). These are usually CLAs with a long tradition and are negotiated at national level (Visser, 1998). As a result, the terms of employment for in-house call centre agents often surpass those for agents working in subcontractor call centres. From the perspective of industrial relations, subcontractor call centres represents a new branch of industry, for which a separate CLA could be negotiated.

In-house and subcontractors also have their own employers' organisation. The Vereniging Contactcenters Nederland (VCN), established in 2003, promotes the interests of in-house call centres, while the Werkgeversvereniging Call centres (WGCC), established in 1998, represents the subcontractor call centres. The WGCC represents 26 of the approximately 250 subcontractor call centres in the Netherlands, including the ten largest, covering $50 \%$ of the total number of jobs in subcontractor call centres..The VCN is an organisation that tries to strengthen the position of the Dutch in-house call centres within the respective parent companies and also to improve the quality of call centres by encouraging call centre certification and promoting training of agents. The VCN, however, is not involved in CLA negotiations. In-house call centres, after all, usually come under the firm or sector agreement of the parent company.

The level of union membership amongst Dutch call centre agents is very low. This can be explained by the fact that many workers often have little affinity with their work, and the total absence of any union structure in most call centres. Almost all in-house call centres (96\%) have a works council, which is compulsory in the Netherlands for companies with more than 50 employees. Of the subcontractor call centres, about three quarters has a works council. A comparison with Germany shows that works councils are a much rarer phenomenon there, in particular in the subcontractor context. In Germany, 70\% of all inhouse call centres has a works council, compared with only $23 \%$ of the subcontractor call centres (Holtgrewe, 2005). 
It is interesting to note that a relatively new sector such as the call centre sector, whose workers moreover operate within the secondary segment of the labour market, nevertheless starts to assimilate within the Dutch labour relations model. Contrary to most other countries, the first CLA for subcontractor call centres was signed by the WGCC and FNV in 2003. This collective agreement had its origins in a firm-specific agreement for SNT, the largest subcontractor call centre in the Netherlands. SNT is the former call centre of KPN, the previously public telecommunications company that privatised its call centre operations. With its connection to a former public company, SNT had a relatively high rate of union membership amongst its agents compared with other subcontractor call centres.

The first CLA for subcontractor call centres only covered a limited number of basic terms of employment: probation period, length of the working week, salary, holidays and special leave, overtime compensation, sickness benefit and travelling expenses. The motive for Dutch employers to sign this CLA was the wish to professionalize the sector, and thus to improve the image of call centre work, reduce recruitment problems, and high turnover rates in call centres. The fact that the Dutch government declared this CLA as generally binding for all firms in the sector concerned, also turned out to have been a motive for employers to close a collective agreement for subcontractor call centres. This prevents other firms from strengthening their competitiveness by not keeping to the terms of the CLA. In our survey of call centre managers, we asked whether the CLA for subcontractor call centres has led to higher labour costs. Only 9\% reported that the CLA had a positive effect on wages, whereas $4 \%$ reported that it increased the number of holidays for their workforce. From this, we may conclude that the primary objective of the first CLA for call centres was to establish the minimum wage level and the number of holidays. Having the agreement declared generally binding, protects employers who want to professionalize the services of their firms and improve their image. Subcontractor call centres have the reputation for being 'cowboy outfits', offering their services at 'knock-down prices', which is partly responsible for the negative connotations associated with the sector.

The first CLA for subcontractor call centres applied to all agents who had a full-time or part-time contract with a subcontractor call centre, but it did not apply to the large number of temporary workers. As the CLA for temporary workers is better in a number of aspects than the one for agents working in subcontractor call centres, ${ }^{5}$ Dutch subcontractor call centres have an incentive for employing agents directly. In this way, they may free themselves from the obligation to pay e.g. additional compensation for overtime in the evenings,

In May 2004, the first CLA for subcontractor call centres expired. A year later, WGCC and the smaller union "Bond van Telecompersoneel" (BTP), agreed to a new CLA with a duration of 17 months. The 2005 CLA includes a wage increase, and sick pay. In addition, a new job level was introduced, for jobs requiring more complex skills. To address concerns about the image of call centre work, a certification program for employees was introduced, that provides agents with a so-called 'starter permit', and a protocol for agent monitoring. Finally, both parties agreed that joint studies would be conducted to investigate the possibilities of a flexible lump sum which employees may use to pay for a pension scheme,

5. For example, the CLA for temporary workers - unlike the one for subcontractor call centres includes a pension scheme, compensation for evening work, and payment of part of the wages into a training fund. 
child care, et cetera. This tailor-made approach goes a step further than the trend towards decentralisation in the Netherlands that was observed by Van der Meer, et al. (2005), in which individual negotiators or employees are given a menu of facilities from which they may make a selection.

The largest union in the sector, FNV, dissociated itself from the CLA result, which was achieved after previous negotiations on the new CLA between the WGCC and FNV had reached an impasse. The CLA was nevertheless declared generally binding for the subcontractor call centres by the Ministry for Social Affairs and Employment. A major point of contention in the negotiations for a new CLA for the subcontractor call centres was the wish of FNV to include in the CLA arrangements on a pension scheme and a job classification system. These wishes were not granted in the current CLA.

The difficulties encountered in negotiating the 2005 CLA for subcontractor call centres illustrate that a new industrial sector, whose personnel works in the secondary segment of the labour market, does not easily conform with the regular Dutch labour relations model. FNV sees a clear parallel between the development of the CLA for subcontractor call centres and the earlier CLA for the temporary workers' sector. In the temporary job agency sector, it took fifteen years to develop a reasonable CLA; in the call centre sector this may be achieved in less time, benefiting from the lessons learned by unions and employers with the temporary agency sector. On the other hand, the new CLA for subcontractor call centres proves that employers can also choose to do business with a sector-oriented union whose primary aim is to 'strive for good relations between employers and employees.'

\section{Conclusions}

Various indicators show that by far the largest part of the labour market for call centre agents in the Netherlands can be classified as a secondary labour market. After all, it is characterised by less favourable terms of employment and working conditions, a large number of part-time and temporary contracts, and a high turnover rate amongst workers. Only a small group of the agents who provide the services to key customers (the 'top desks') working in in-house call centres would be classified as being in a primary labour market segment. Within the secondary segment, we found evidence of a further segmentation between the in-house call centres, offering relatively better jobs, and the subcontractor call centres where terms of employment and working conditions for agents are less favourable. Subcontractor call centres also invest much less in training for their workers, and employ more agents with part-time contracts and more temporary workers. In addition, turnover in subcontractor call centres is much higher than in in-house call centres.

The origin of the dual nature of the labour market for call centre agents in the Netherlands lies in the difference between the collective labour agreements (CLAs) that apply to the agents in the in-house and subcontractor contexts. Agents working in in-house call centres usually come under the jurisidiction of the firm's CLA or sector CLA. On the other hand, subcontractor call centres constitute a new industrial sector with its own CLA. Recent developments in industrial relations have shown that the establishment of a new sector such as the call centre sector - whose workers, moreover, are working in a secondary labour market - in the Dutch labour relations model, is by no means an automatic process 
(cf. Heery, 2005). The first CLA for subcontractor call centres was signed in 2003. This is a unique development based on comparisons with other countries involved in the global call centre study. Probably, the possibility of declaring a CLA as generally binding, which exists in the Netherlands, played a major role here, because it protects employers in the sector who wish to professionalize the sector against competition from 'cowboy outfits'. The 2005 CLA, however, reveals a quite different type of dynamic. After CLA negotiations between the WGCC and the FNV union stalled, the employers' organisation agreed to a new CLA with a sector-oriented union that puts the joint interests of employees and their employers first. The latter may have its own motivation, as evidenced by a remarkable clause in the negotiation agreement: "Considering the specific nature of the sector, tailor-made solutions in terms of employment are of great importance. In this light, a study will be conducted into the possibilities of a different provision of terms of employment, the so-called lump-sum or totalcash system." It may be assumed that the costs of this tailor-made solution are lower than the costs of traditional terms of employment existing elsewhere in the Dutch economy. Although this new CLA will help to anchor subcontractor call centres into Dutch industrial relations, it will also strengthen the secondary nature of the labour market for agents in subcontractor call centres.

\section{References}

Alexander, A.J. (1974), Income, Experience and Internal Labour Markets, Quarterly Journal of Economics, Vol. 88, pp. 63-85.

Batt, R. (2001), Explaining wage inequality in telecommunications services: Customer segmentation, human resource practices and union decline, Industrial and Labor Relations Review, Vol. 54, pp. 425-449.

Batt, R., Doelgast, V. \& Kwon, H. (2005), The U.S. Callcenter Industry 2004, National Benchmarking Report, Ithaca, NY: Cornell University.

Datamonitor (2002), Callcenter Industry Profile: the Netherlands, New York: Datamonitor.

Deery, S. \& Kinnie, N. (2004), Call Centres and Human Resource Management, A Cross-National Perspective, Houdmills/New York: Palgrave Macmillan.

De Grip, A., Hoevenberg, J. \& Willems, E. (1997), Atypical Employment in the European Union, International Labour Review, Vol. 136, pp. 49-71.

Dekker, R., De Grip, A. \& Heijke, J.A.M. (2002), The effects of training and overeducation on career mobility in a segmented labour market, International Journal of Manpower, Vol. 23, pp. 106-125.

Doeringer, P.B. \& Piore, M.J. (1971), Internal labor markets and manpower analysis, Heath Lexington Books, Lexington.

Freeman, R. (1998), War of the Models: Which Labor Market Institutions for the 21st Century? Labour Economy, Vol. 5, pp. 1-24.

Heery, E. (2005), Sources of change in trade unions, Work, Employment and Society, Vol. 19, pp. 91106. 
Holman, D. (2002), Employee Wellbeing in Call Centres, Human Resource Management Journal, Vol. 12, pp. 35-50.

Holman, D., Wood, S. \& Stride, C. (2005), Human Resource Management in Call Centres, University of Sheffield: Institute of Work Psychology.

Holtgrewe, U. (2005), Callcenters in Germany, Preliminary findings from the Global Call Centre Project, Duisburg: Essen University.

Kalleberg, A.L. (2000), Nonstandard Employment Relations: Part-time, Temporary and Contract Work, Annual Review of Sociology, Vol. 26, pp. 341-365.

Koene, B., Paauwe, J., \& Groenewegen, J. (2004), Understanding the Development of Temporary Agency Work in Europe, Human Resource Management Journal, Vol. 14, pp. 53-73.

Lanciano-Morandat, C., Nohara, H \& Tchobanian, R. (2005), French Call Centre Industry Report 2004, LEST: Aix-en-Provence.

Osterman, P. (1982), Employment Structures Within Firms, British Journal of Industrial Relations, Vol. 20, pp. 349-361.

Roland, T. (2000a), Call Centres in Europe: Part One, European Industrial Relations Review, Vol. 320, pp. 13-20.

Roland, T. (2000b). Call Centres in Europe: Part Two, European Industrial Relations Review, Vol. 321, pp. 13-19.

Taylor, P. \& Bain, P. (1999), An Assembly Line in the Head': Work and Employee Relations in the Call Centre, Industrial Relations Journal, Vol. 30, pp. 101-117.

Taylor, P., Baldry, C., Bain, P. \& Vaughan, E. (2003), 'A unique working environment': health, sickness and absence management in UK call centres, Work, Employment and Society, Vol. 17, pp. 435-458.

Taylor, P., Mulvey, G., Hyman, J. \& Bain, P. (2002), Work Organization, Control and the Experience of Work in Call Centres, Work, Employment and Society, Vol. 16, pp.133-150.

Van der Meer, M., Visser, J., \& Wilthagen, T. (2005), Adaptive and Reflexive Governance: The Limits of Organized Decentralization, European Journal of Industrial Relations, Vol. 11, pp. 347-365.

Visser, J. (1998), Two Cheers for Corporatism: One for the Market: Industrial Relations, Wage Moderation and Job Growth in the Netherlands, British Journal of Industrial Relations, Vol. 36, pp. 269-292. 